\title{
Modern Approaches and Constructive Solutions for New Oil and Gas Condesate Deposits in Russia
}

\author{
Viktoriya A. Merkulova*', Kiselev Vladislav"*, Sorokin Viktor ${ }^{\text {**** }}$ \\ *Candidate of Technical Sciences, Associate Professor of the Department of Descriptive Geometry and Graphics, \\ Saint-Petersburg Mining University, Saint Petersburg, Russian Federation. \\ ** Student of Saint-Petersburg Mining University, Saint Petersburg, Russian Federation. \\ **Student of Saint-Petersburg Mining University, Saint Petersburg, Russian Federation.
}

\begin{abstract}
Among oil and gas condensate fields being developed in Russia, the group of Messoyakha deposits, the most Northern ones located on shore, not far from the Arctic Circle, is of particular interest.

The article deals with modern technologies of development of hard-to-recover oil reserves with the use of advanced methods of development group of the "Messoyakha" deposits. Modern technologies of development are the key to the successful development of a group of the "Messoyakha" deposits. The work has been carried out to estimate an effectiveness of the methods of increasing oil recovery and geological and technical measures. The necessity to drill high-tech wells with application of hydraulic fracturing is revealed. The basic problems of oil extraction are defined and ways of their elimination are developed. Thus, developing the present, based on the past, building the future.
\end{abstract}

Keywords: group of the Messoyakha of fields, Fishbone drilling, modern technologies, oil and gas deposits, a high level of production

\section{INTRODUCTION}

Effective development of oil reserves requires application of advanced technologies. Their implementation makes it possible to develop fields in new regions, which until recently seemed unprofitable, and today should reach a higher level of production, which is very important for a group of the "Messoyakh" deposits.

A few years ago, the thickness of the oil reservoirs was 20-30 meters, and now - 3-5 meters. At the same time, their permeability decreased tenfold. This significantly reduces the rate of oil inflow to wells and reduces oil production. To make the development of such deposits effective, it is necessary to change general approach to the development and to the utilization of high-tech drilling. For the first time in GazpromNeft drilling has been carried out based on the technology called "Fish bone" (Fishbone).
On the Gydan Peninsula, 250 kilometers away from the Arctic Circle, the Messoyakha group is located in the Arctic climate zone, which consists of Eastern and Western fields. The main logistic feature of the project is the absence of oil and gas transportation communications in the region. The opening of the Messoyakha group of deposits took place in the 1980s. The launch of the Vostochno-Messoyakhskoye field into commercial development took place on September 21, 2016. The Western-Messoyakhskoye field is under exploration.

The license to develop the Western-Messoyakhskoye and the East-Messoyakhskoye areas received by company "Zapolyarneftegasgeologiya" in 1998 and in 1999 the company was renamed to "Messoyakhaneftegaz". This company has been obtained by «Slavneft» for the realization of a project in Tyumen in 2011, «Slavneft» has created a branch «Messoyakha» «Gazpromneft-Development», subsidiary of «Gazpromneft», in December "Gazpromneft" and "TNK-BP" became the shareholders of "Messoyakhaneftegaz" on an equal footing. In 2012 first oil has been extracted at the East-Messoyakhskoe field.

Currently, TNK-BP is a part of oil company RosneftMessoyakhaneftegaz and becomes a joint venture of Gazpromneft and Rosneft. In 2014, construction of the infrastructure has begun. In 2015 exploration drilling has started, and on September 21, 2016, commercial development of the East-Messoyakhskoye has begun.

"Messoyakhaneftegaz", joint venture "Gazprom" and "Rosneft" has completed production plan of 2016. 3 months since start of commercial development of the EastMessoyakhskoye field (Yamal, Gydansky Peninsula) volume of crude oil amounted to more than 701.5 thousand tons, and average rate of an annual daily production has reached 7000 tons/day.

As of June 2017, 2 million tons of oil has been extracted at the East-Messoyakhskoye field. Drilling and commissioning of new multilateral wells with application of modern technologies and methods of intensification of oil inflow rate has allowed to achieve this result. 


\section{METHODS}

The object of our study is a group of the "Messoyakha" deposits.

The aim of the study is to research modern technology of construction and development of main reserves of the PK-1 oil reservoir.

\section{Research problem:}

1. Study of the peculiarities of oil and gas deposits of the group "Messoyakha" deposits.

2. The analysis of the PK1 layer in the zones of the collector.

3. Identification of the main problems and ways to solve the development of cyclites A and B.

4. The possibility of using 3D modeling in the formation of a three-dimensional model of oil stratum.

The PK-1 oil statum of the "East-Messoyakhskoye" field has been adopted as an analysis model.

The revealed features of oil and gas deposits are:

1. The shallow occurrence of the species $(800 \mathrm{~m})$;

2. Presence of a gas cap and underlying water;

3. Low temperature of stratum $\left(16{ }^{\circ} \mathrm{C}\right)$;

4. A high tendency of clay particles of the reservoir rock to swell;

5. Slightly modified highly permeable Sandstone $(\sim 1$ D);

6. High viscosity of oil (111spz);

7. Block structure with high heterogeneity of geological and physical characteristics on cyclites;

8. Separate levels of gas-oil contact / water-oil contact inside the section;

9. Weak predictability of channel sediments of cyclite B. Fig.1.

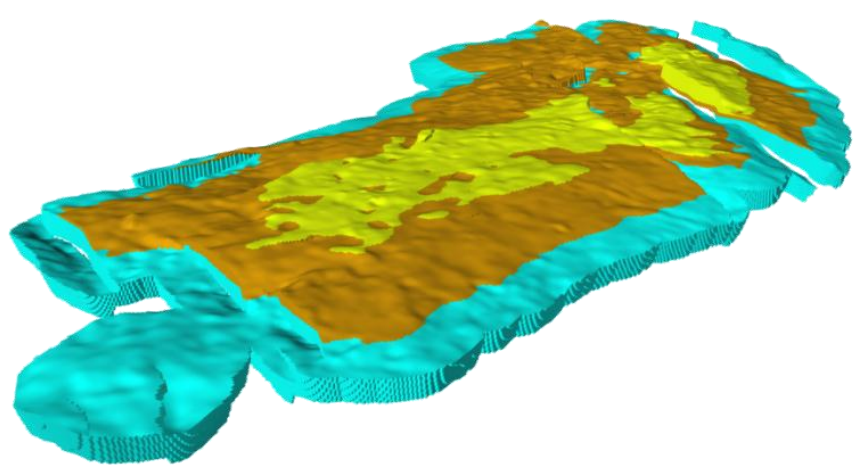

Figure 1. The main oil stratum $\mathrm{PC}-1$

During drilling of the PK-1 object, the project design study for new wells has not been confirmed. An analysis of the wells production rates has shown that reasons for non-confirmation is a more intense dynamics of flooding and low starting debits, moreover it depends on the location of wells in the reservoir area.
Table 1. Comparison of reservoir properties in the bundles of the PK-1 oil stratum

\begin{tabular}{|l|c|c|}
\hline Characteristic & Bed & Floodplain \\
\hline Oil saturated thickness, m & 22 & 19 \\
\hline Porosity factor, \% & 31 & 29 \\
\hline The coefficient of permeability, MD & 1384 & 809 \\
\hline Dismemberment & 12 & 21 \\
\hline
\end{tabular}

Thus, according to table 1 , it can be seen that because of drilling a large quantity of wells in the PK-1 reservoir, zones characterized by various filtration-capacitive properties have been identified:

- Bed deposits are the Central part of the stratum, which are represented by an aged collector with high filtration-capacitive properties;

- Floodplain deposits - are peripheral areas are represented, as a rule, deposits of degraded and high roughness [4].

The results of lithological-stratigraphic description of an opened part of cut are based on the study of drilling data of prospecting and exploration wells, the description of core material and oil and gas potential of the territory.

In the bedside Senoman part of the Pokursky Suite, the PK-1 reservoir, within the East Messoyakhskoye field, divided by discontinuous violations of shielding type into 11 blocks, is the largest in size and in reserves of oil and gas of the gas cap.

Using 3D modeling of geological characteristics of zones and their comparison shows that the Central part is much more permeable than the peripheral. The conditionally allocated zone of channel deposits is mainly saturated with water; the oil part of this pack has the maximum oil-saturated thicknesses in the Central part of the Deposit. Consequently, more active development of reserves will be observed in the Central part of the Deposit, complicated by high water content of products. In the edge zones, the process of extracting reserves will be complicated by low productivity, but with the use of new technologies that increase the coverage of the impact on the reservoir, the efficiency of development will increase.

The main problems are revealed:

1. Inability to select a unified solution and the need to develop technological solutions for each cyclite separately;

2. Carrying out advanced experimental-industrial works in each direction of development of technological challenges;

3. Technological challenges of experimental-industrial works of hydraulic fracturing: growth restriction of crack height, selection of the hydraulic fracturing fluids, management of complex geometry of the crack, combination with dust suppression technologies. 
The main reserves of the oil stratum are represented by cyclites $^{1}$. Fig. 2 .

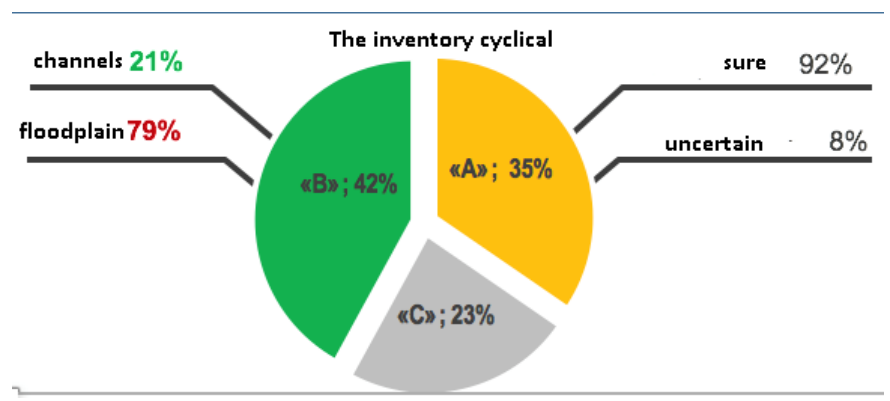

Figure 2. The inventory cyclical

The main problems on cyclites $« \mathrm{~A}+\mathrm{B} »$ :

1. Low predictive ability of mapping channels of the cyclite B.

2. High compartmentalization of the cyclite B (20).

3. Low filtration-capacitive properties of floodplain part of cyclite B (from 10 to $200 \mathrm{mD}$ ).

4. Indefinite productivity of cyclite A.

5. Low filtration-capacitive properties of cyclite A (from 5 to $150 \mathrm{mD}$ ).

Based on the analysis of the studies, following ways of cyclites A and B development have been adopted:

1. Basic technology - in-line system with a horizontal well $1000 \mathrm{~m} \mathrm{~m} / \mathrm{R}$ distance $-300 \mathrm{~m}$.

2. Alternative technology No. 1 - Fishbone drilling instead of horizontal wells. Fig. 3.

3. Alternative technology number 2 - multistage hydraulic fracturing in floodplain zone. Fig.3.

Technology No. 1

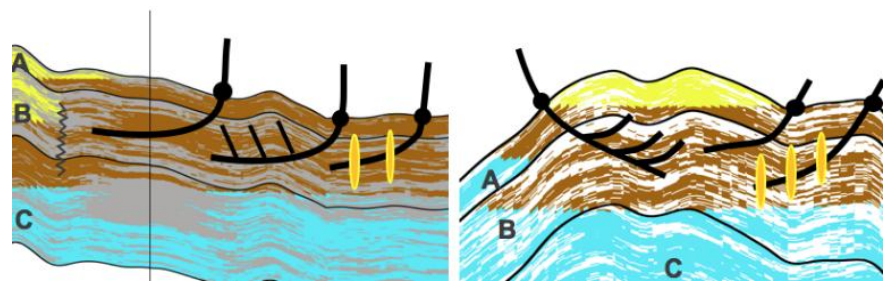

Figure 3. Possible options for the development of
As part of the search for optimal technology of development of the reservoir areas following experimental-industrial works have been partially carried out and planned to be conducted:

1. Fishbone well drilling.

2. Hydraulic fracturing and multistage hydraulic fracturing of the PK-1 reservoir.

3. Maintenance of the reservoir pressure with implementation of a sealed grid of wells on different systems and different design of injection wells.

4. Physical-chemical methods-polymer injection.

For designing a full-scale field development it is necessary to utilize modern technological and organizational solutions:

1. Fishbone well drilling. Such design of the well allows simultaneously draining reserves at different depths and significantly increasing the coverage of oil-saturated areas of the reservoir in comparison with the coverage of the traditional horizontal well. Fishbone design allows to direct each branch hole into separate oil areas in a given vector. Fishbone drilling at the VostochnoMessoyakhskoye field in the PK-1 oil stratum area carried out experimental-industrial tests of technology of construction multilateral wells for new construction called a fishbone. This name the technology has recieved due to the design features of wells, when the main horizontal well depart in numerous branches. This creates a well, in its form resembling the skeleton of a fish. This technology is an alternative to the application of hydraulic fracturing. The purpose of the technology, as with fracturing, is to increase production rates of wells by better connecting the reservoir to the well bore. This technology has been tested at foreign oil deposits in carbonate reservoirs and in the extraction of methane from coal seams. At the VostochnoMessoyakhskoye field, it has been tested in very intermittent terrigenous oil-saturated sediments.

2. Drilling horizontal wells with multi-stage hydraulic fracturing - hydraulic fracturing high-gradient collector layer PC-1 is important to increase the connectivity of layer thickness. Drilling of a tight grid $(150 \mathrm{~m})$ has shown that drilling in areas with high permeability and porosity does not lead to loss of well productivity and allows to develop the reservoir fully without waiting for infill drilling at a later period, and also allows you to keep oil production at the designed level.

3. Organization of reservoir pressure maintenance by (single - row system) - design development system (distance between rows $-300 \mathrm{~m}$ ) with transformation into three-row (distance between rows-150 m) drilling of well doubles.

4. To apply physical-chemical methods - at the stage of high water cut production with the aim of changing flow filtration using washed channels and to displacement of oil reserves is considered an injection of polymers.
${ }^{1}$ Cyclites-natural combinations of layers of sedimentary rocks caused by cyclic change of conditions of their formation. 


\section{DISCUSSION AND CONCLUSIONS}

There are currently a large number of studies about development of oil and gas condensate deposits, such as Excavation work [Electronic resource] //fracture - what is it URL:

http://www.earthworksaction.org/issues/detail/hydraulic_fract uring_101\#.WmsBQCNeP-Y; Boun Michael berry Smith, Carl T. Mongomery hydraulic fracturing Copyright Taylor and Francis group LLC, Houston, Texas. ISBN number 9781466566859, 2015.- 812; I. P. Zaikin, K. V. Kempf, Gottlieb, O. L., Efimov S. V., Vikhristyuk, S. V., Nasyrov, A. M., 2010. Extensive experience drilling in OJSC Udmurtneft ROGTEC Russian petroleum technology, 24: 46-54; Voronin A., Gilmanov J., Eremeyev D., Dubrovin A., Abaturov N., Perunov A. (2017, 16 October). The analysis of rotor-driven systems for lateral borehole in open multilateral boreholes at the Vostochno-Messoyakhskoye field is carried out. Society of Petroleum engineers. doy: 10.2118/ 187702-Ms.

There are important differences in Russian Fishbone technology from the Western one, in which drilling pipes are assembled on the surface. In our case, construction is performed during the construction of a horizontal well, when the drilling of side holes on the overlying oil spill is performed from a certain point. That is, the drilling of branches occurs when drilling the main barrel. Fishbone technology can significantly increase the coverage of oilsaturated areas of the reservoir in comparison with traditional horizontal well, and with a smaller volume of drilling operations compared to a multilateral well. The design allows you to direct each branch in a separate oil areas, without affecting the adjacent layers of gas or water. Well branches can depart in any direction from a horizontal trunk, and their cost is much lower, than expenses on drilling of separate wells. However, the process of drilling such wells is much more complicated. Sequence of works at construction of wells by Fishbone technology at the Vostochno-Messoyakhskoye field:

Drilling of the main horizontal section of well to a certain depth is carried out, at which, because of a sharp curvature, the first lateral branch with a set of zenith angle and an azimuth deviation from the direction of the well.

Next, drill pipes are lifted to a depth of the interval of the set of side branch parameters beginning cut in an open barrel with a drop in the zenithal angle and wiring of the main wellbore with stabilization of horizontal section of the initial azimuth.

Drilling of several branches is carried out in the same manner. The main wellbore, constantly time drilling and extending from the side branch saves the azimuth of the drilling is essentially unchanged. The main wellbore is lined up by, a filter shank, side branches are not lined up.

As far back as 20 years ago, there was a lot of confusion about technology of multilateral drilling. There were not established universal terms describing the technology. Not enough of classification of various types of multilateral wells according to complexity, risk, type of articulation of the wellbores. In the end, in 1997 on the initiative of Eric Diggins from the company Shell the forum has been convened, titled
"Technology Advancement - Multi-Laterals (TAML)". The purpose of the forum was to unify approaches for the further development of multi-core drilling technology. at this forum, experts from the world's leading oil companies shared their experience in the use of technology and came to a common classification of multi-core wells in complexity and functionality.

A multi-lateral well is a well with one or more additional side holes from the main wellbore. This can be a normal production well or lateral well/trunks drilled from an existing well.

A successful multi-lateral well, replacing several "traditional" wells, is able reduce the overall cost of drilling and completion, increase productivity, and ensure a more efficient flow of oil from the reservoir. Moreover, the use of multilateral wells can provide more effective management of the field development as a whole and increase the oil recovery rate.

The practical significance of the study is to change the general approach to development and application of the high-tech drilling:

- $\quad$ For the first time in GazpromNeft, drilling has been carried out with utilizing of Fishbone technology the technology of drilling the main horizontal wellbore to a certain depth with drilling of side branches and a set of zenith angle with an azimuth deviation from direction of the main wellbore.

- Advanced development work, drilling and commissioning of new wells with multiple wells has been carried out;

- Necessity of the high-tech wells drilling with utilization of hydraulic fracturing has been proved;

- Technologies and methods of intensification of oil inflow has been applied;

- 3D modelling of geological characteristics of the areas has been used;

- Hydraulic fracturing fluids to limit growth and control complex geometry of the crack, combining with dust-suppression technologies have been selected;

- Development of cycles A and B using basic and alternative technologies has been done;

- At the East-Messoyakhskoye field 9 fish bones TAML level-1 have been built and two doublewellbore well with level of complexity TAML-2. The project had been successfully implemented, a positive result was obtained. Increase in start-up debits was up to $60 \%$ in comparison to horizontal well, the increase in net present value of NPV up to $45 \%$. 


\section{REFERENCES}

[1] Boyun Guo, Kai Sun, Ali Ghalambor (2008) well productivity Handbook [Copyright the Publishing company, Houston, Texas]. ISBN 9780127999920, $334 \mathrm{C}$.

[2] Rogachev M.K., Kondrashev A.O. (2016) [Substantiation of intrastratal water shutoff technology in low permeability reservoirs [Proceedings of the Mining Institute]. ISSN 01353500. T.217, Vol. 55-60 C.

[3] Alekseev A.D. Study of hard-to-recover and nontraditional objectsaccording to the principle of "factory manifold in the reservoir" / A. D. Alexeev, V. V. Zhukov, K. V. Strizhnev, S. A. Cherevko //Proceedings of the Mining Institute. 2017. 695-704. DOI: 10.25515/PMI.2017.6.695, Vol. 228. C.

[4] Messoyaha Neftegaz (access: 01.10.2017) [Electronic resource] $/ 2$ million tons of extracted oilURL: http://mesng.ru/press-center/smi-o-nas/2mlntonns-nefti-dobito/

[5] Messoyakha Neftegaz (accessed: 01.10.2017) [Electronic resource] //Messoyakhaneftegaz fulfilled the plan of oil production in 2016-URL: http://mesng.ru/press-center/smi-o-

nas/Messoyakhaneftegaz-vipolnil-plan-dobichi-nefti/

[6] Kiselev V. I., Sorokin V. V., Merkulov V. A. (date accessed: 26.01.2018) features of the location and development of technologies of MESSOYAKHA group of fields /scientific community of students of the XXI century. Engineering science: a collection of articles on the Mat. XVIII international. stud. science.- practice. Conf. No. 10 (57). URL: https://sibac.info/archive/technic/10 (57). PDF

[7] Gazprom Neft (date of application: 26.01.2012) [Electronic resource] /messoyaha project: a unique technology for the development of the mainland of Russia's Northern oil fields URL: http://http://ntc.gazprom-neft.ru/research-anddevelopment/papers/13547/

[8] Нефтегаз.RU (date of access: 26.01.2010) [Electronic resource] /Fishbone. Messoyahaneftegaz tested a new technology for drilling horizontal wells that do not require fracturing-URL: https://neftegaz.ru/news/view/153464-Fishbone.-

Messoyahaneftegaz-oproboval-novuyu-tehnologiyubureniya-gorizontalnyh-skvazhin-ne-trebuyuschuyugidrorazryva-plastov//

[9] All about oil (date accessed: 26.01.2018) [Electronic resource]// multi-lateral wells: the development of technology address: http://vseonefti.ru/upstream/mnogostvolnyeskvazhiny.html

[10] Directional drilling and basics of the black sea region: (2015)Textbook. — 2nd ed. - M.: INFRA-M; Krasnoyarsk: Sib. Fader. UN - t, 336 p.
[11] Severpress(date accessed: 26.01.2018) [Electronic resource] /Eastern messoyaha produced more than 3 million tons of oil. Plans for the future are impressive //http://sever-press.ru/ekonomika/neft-igaz/item/35999-vostochnaya-messoyakha-dalabolee-3-millionov-tonn-nefti-plany-na-budushcheevpechatlyayut

[12] Gazprom Neft (date of application: 26.01.2012) [Electronic resource] / / well in the form of //http://www.Gazprom Neft.Bathroom/press center/Sibneft online/archive/589/1114979/

[13] Built-in URL Messoyaha gas (date of access: 26.01.2010) [Electronic resource] /Messoyaha well with a record number fishbons are: http://mesng.ru/press-center/novosti/record_fishbon/ 